\title{
Políticas Urbanas no Brasil nos Últimos Trinta Anos ${ }^{1}$
}

\author{
Aristides Moysés * \\ Genilda D'Arc Bernardes ** \\ Maria do Amparo Albuquerque Aguiar ${ }^{* * *}$
}

\begin{abstract}
$\mathrm{R}$ Lesumo: o objeto central desse artigo é discutir a implementação de políticas urbanas no Brasil nos últimos trinta anos (1970-2000). Durante este período constata-se mudanças fundamentais no panorama político-económico do país. Esgotou-se o modelo desenvolvimentista e se instalaram políticas liberais, que afetaram a condução do Estado frente aos problemas urbanos que, em razão do modelo anterior, também tiveram seu perfil modificado.
\end{abstract}

Palavras-Chave: desenvolvimentismo; urbanização; política urbana; orçamento participativo.

\section{Introdução}

Políticas específicas voltadas para as cidades têm sido largamente discutidas, inclusive em razão do processo acelerado de urbanização, que expôs a pobreza, antes parcialmente escondida no campo. Esse processo que, no Brasil, se intensifica a partir do pés-Segunda Guerra Mundial, está ligado também à industrialização, que teve grande impacto sobre toda a população e provocou a intensificação dos processos migratórios.

A política de interiorização explicitamente posta em prática desde o governo Vargas no período 1930/1945, notadamente com a Marcha para o Oeste, se por um lado estimulou a entrada para a zona rural, também favoreceu o aparecimento e o crescimento de cidades que abrigaram uma parcela da população que demandou o interior.

Esses deslocamentos populacionais não se verificaram de forma espontânea, exclusivamente. Foram também largamente patrocinados pelo Estado, no interesse de alargar os mercados para sustentar a instalação de um parque industrial que se implantava, como também para reforçar o comércio exportader.
A partir dos anos 50, os planos nacionais estiveram em evidência, como forma de garantir o desenvolvimento da produção e do mercado, capitaneado pelo estado.

O Plano de Metas do governo Juscelino Kubistcheck (JK-1956/1960) marcou profundamente o desenvolvimento econômico, intensificando os fluxos migratórios entre as regiões, sendo que o crescimento urbano foi preponderante sobre o rural. Brasília, meta síntese de seu plano, foi fundamental nessa época

Dessa forma, nas primeira fase do desenvolvimentismo, os grandes problemas urbanos localizavam-se preponderantemente no eixo Rio de Janeiro/São Paulo e eram enfrentados pelos governos municipais. Intervenções importantes verificaram-se no espaço físico dessas cidades que, em razão de serem grandes centros concentradores de população, requeriam maiores atenções sob esse aspecto. As políticas federais dirigidas à população urbana eram de caráter geral, muito mais voltadas para as áreas de saúde, educação e transporte, mas sua execução estava sob a responsabilidade dos

\footnotetext{
* Professor do Departamento de Economia da Universidade Católica de Goiás. Diretor do Departamento de Ordenação Socioeconômico da Secretaria Municipal de Planejamento da Prefeitura de Goiânia. Coordenador e Pesquisador do GEPUR-CO- Grupo de Estudos e Pesquisas Urbanas do Centro-Oeste. Contacto: arymoyses@brturbo.com

** Professora do Departamento de Artes e Arquitetura da Universidade Católica de Goiás - UCG e Professora do Mestrado em Sociologia da Universidade Federal de Goiás. Pesquisadora do GEPUR-CO-Grupo de Estudos e Pesquisas Urbanas do Centro-Oeste. Contato: genilda@hotmail.com

*** Economista, professora do Departamento de Ciências Sociais da Universidade Federal de Goiás e do Mestrado em Sociologia da Universidade Federal de Goiás e do Mestrado em Agronegócios/UFG. Contato: mamparo@zaz.com.br.

1 As ideias centrais desse artigo foram discutidas na 54. ${ }^{a}$ Reunião da Sociedade Brasileira para o Progresso da Ciência, realizada em Goiânia no período de 7 a 12 de Julho de 2002 - Universidade Federal de Goiás - Campus II Samambaia - Simpósio - Cidades Brasileiras: Culturas e Políticas Públicas.
} 


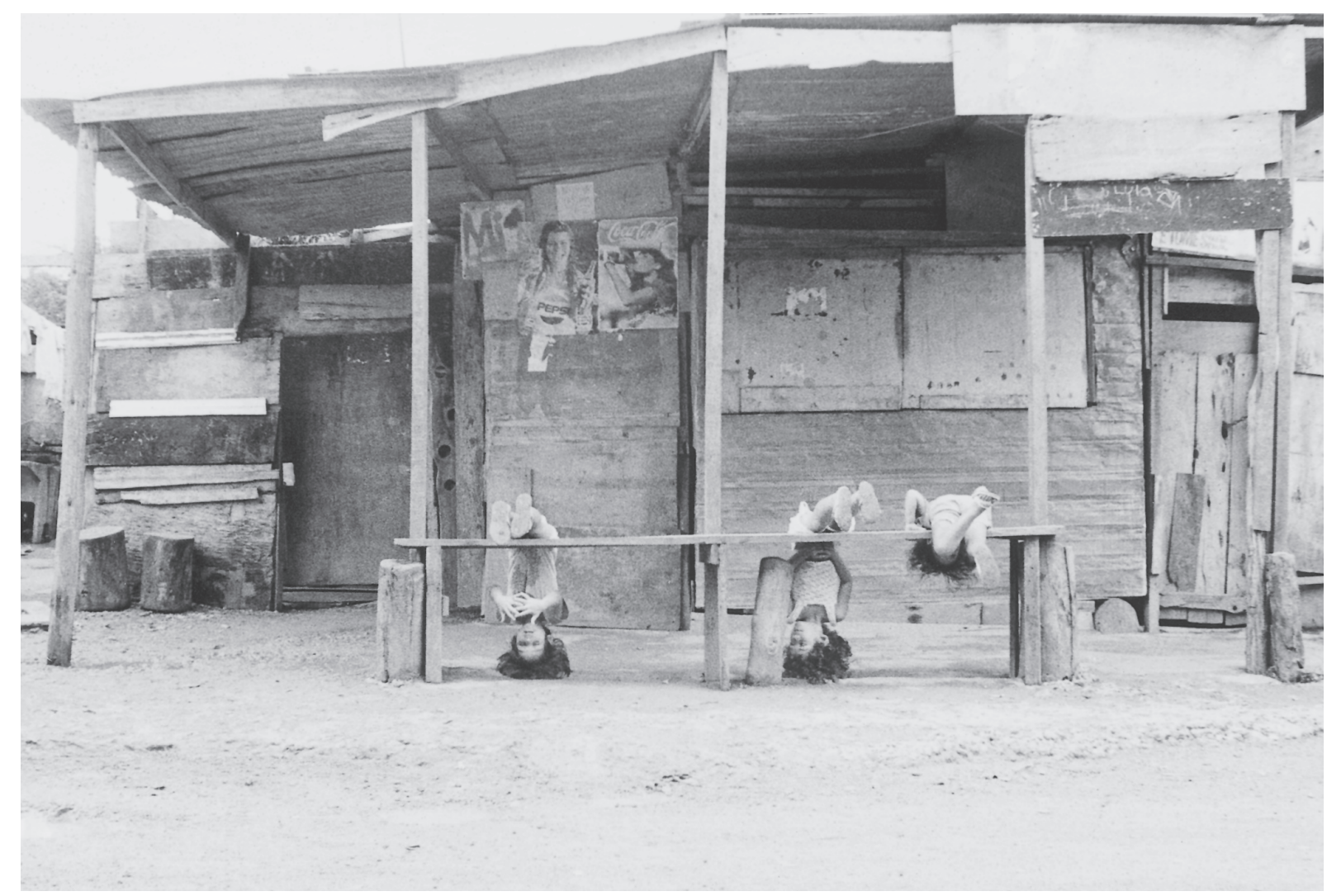

Vila Paranoá/Periferia de Brasília, 1995. Foto de Marcelo Feijó.

poderes estaduais e municipais. A grande preocupação do governo federal estava voltada para a implantação de uma infra-estrutura para a sustentação do parque industrial, pois nesta meta estavam depositadas as esperanças da dinamização econômica do país.

A crise político-econômica desencadeada nos anos 60 levou os militares ao poder, período em que as questões urbanas ganharam grande destaque. Durante os primeiros anos dos governos militares, o Estatuto da Terra contribuiu para apressar a saída de um grande contingente da população rural para as cidades. Este processo intensificou-se com a política de crédito voltada para a modernização dos procedimentos na agricultura e o financiamento de máquinas agrícolas, causando a liberação de mais trabalhadores do campo.

\section{Políticas Urbanas nos Governos Militares}

Os governos militares promoveram uma reforma de largo âmbito no aparelho administrativo do País, no sentido de distanciar a participação popular do crescimento da riqueza produzida e, também, desencadear uma nova fase de ampliação da industrialização e aumento da produção em geral. A preparação da logística administrativa assumiu grande importância, pois foi aí gestada a tecno-burocracia que respaldou as políticas públicas em geral e, em particular, as políticas urbanas.

É conveniente notar que, nessa nova fase, já havia um maior contingente populacional disperso em vários outros centros, com as atividades urbanas propagando-se para outros estados, embora a grande concentração ainda se mostrasse mais preocupante no Rio de Janeiro e em São Paulo.

Os anos 60 e 70 foram particularmente ricos na produção de políticas urbanas e regionais. Procurava-se alcançar níveis altos de crescimento econômico e manter o controle do mesmo, fomentar a capitalização das regiões que permaneciam com baixa produtividade, integrando-as às tecnologias mais modernas, dotando-as de infra-estrutura de estradas, e criar cidades que pudessem dar suporte político-administrativo ao processo que estava instalado. 
Este forte estímulo surtiu efeitos intensos no perfil regional e urbano, levando à criação de novos instrumentos de política que tentavam não perder o controle dos acontecimentos, decorrentes do crescimento da população nas cidades. Houve empenho por parte dos governantes em aproveitar esse fato para a dinamização de determinadas atividades, notadamente da construção civil. Tem-se aí um veio que foi largamente explorado. No âmbito regional, fomentou o aparecimento das grandes empresas de construção civil, encarregadas da implantação de estradas, pontes e grandes obras. Por outro lado, uma parcela considerável da população, dispensável nas atividades agrícolas, foi aproveitada nessas obras e, nas cidades, para a expansão habitacional, propiciando não só maiores oportunidades de diversificação de atividades como o crescimento dos empreendedores imobiliários, com amplas possibilidades de acumulação.

Sabe-se, no entanto, que grande parte das discrepâncias que se estabelecem nas cidades não se encontram vinculadas apenas aos aspectos físico-territoriais, mas dependem de um conjunto de fatores muito mais abrangentes que envolvem economia, política, cultura, regras sociais e tantos outros fatores. Esses encontram-se profundamente intrincados, e as dificuldades de mediação do estado, face à extrema dinâmica das situações apresentadas, revelam a capacidade que tem a sociedade de se renovar e, também, de acrescentar soluções imaginosas para os problemas que, entretanto, crescem de forma muito mais significativa.

A dinâmica socioeconômica trouxe elementos como migrações, desemprego, que acentuaram as heterogeneidades através da má distribuição da renda, gerando as mais diversas respostas nos diversos subespaços que compõem a cidade que, no seu todo, passa a conviver com a nova situação. Essa convivência é, quase sempre, conflituosa e, frequentemente, requer intervenções dos poderes constituídos.

A passagem de um Brasil com população predominantemente rural para um país predominantemente urbano aconteceu durante os governos militares (anos 70) e influenciou largamente os planos de governo e a tomada de decisões sobre políticas voltadas para as cidades. A preocupação com o controle físico das cidades e com o desenvolvimento de atividades urbanas esteve vinculada à necessidade do Estado - a essa época largamente intervencionista - conduzir o processo, bem como tentar converter essa população que se urbanizava em consumidores, dando sustentação à expansão da economia. Foi uma fase com forte tendência para o planejamento em vários níveis - global, regional e local -, além de terem surgido programas especiais setoriais com abrangência ampla. Procurou-se sistematizar, através dos planos, as ações de governo, o que não significa que grande parte delas tenha sido implementada, ou que os resultados das que foram executadas tenham sido aqueles preconizados como efetiva solução para os problemas de pobreza que se manifestavam de uma maneira geral e particularmente nas cidades.

O conjunto de problemas e a escassez de recursos com que normalmente se defrontam os governantes estavam presentes nos governos militares. Entretanto, eles dispuseram de facilidades também pouco usuais. Assim, as decisões centralizadas e a facilidade de captação de recursos financeiros internacionais foram fatores favoráveis à proliferação de planos, propostas e estudos sobre cidades e regiões. Tais planos, respaldados por ampla legislação, introduziram alguns modelos que marcaram a história do planejamento urbano e regional, uma vez que se constituíram numa espécie de base que foi incorporada pelos planejadores e que, mesmo hoje, com as diferentes condições econômicas e políticas, referenciam atitudes de planejamento.

Assim, os governos militares deixaram para estudo uma "família de planos" que denota a preocupação em realizar um projeto de crescimento controlado e, para tal, necessário se fez alargar o leque das preocupações com as normas capazes de garantir esse intento.

Todo esse período, em que foi reforçada a tecno-burocracia, deixou um grande acervo de medidas e leis que foram superadas por outras, renovaram-se através do tempo ou tiveram que se atualizar. Algumas outras, que não chegaram a entrar em vigor, por inoportunas, encontram agora seu tempo e ressurgem em novo contexto.

Considerando-se o desenho urbano, desde os mais simples, como normatizadores das cidades, o Brasil, desde os primórdios de sua colonização, dispõe de instrumental para controle da vida nas cidades. Dessa forma, chegamos ao século XX com influências de normas de cidades européias ou norte-americanas, que tentam amenizar os 
problemas decorrentes da urbanização que se intensifica através das populações mais pobres que transitam entre cidades ou se transferem da zona rural pela falta de condições para ali permanecerem, pela perspectiva de melhores condições de vida ou por ambas as razões.

Tendo como referência o pós-guerra, quando se intensificou o processo de industrialização no Brasil e também o da urbanização, toma vulto o planejamento governamental através de metas que contemplam aspectos estratégicos, nos quais aparece como particularmente importante a infra-estrutura econômica. Em todos, entretanto, se faziam presentes, de forma relevante, os aspectos ligados à saúde, educação, habitação, todos voltados de forma marcante para o meio urbano. Nos últimos tempos, a idéia de se regular as cidades tem a finalidade de diminuir os impactos provenientes das mudanças não só na zona rural como também do conjunto das próprias cidades, atualmente centros geradores da maior parcela de riqueza do país.

Constata-se, portanto, que as cidades brasileiras têm sido alvo constante de preocupações governamentais, através da adoção de políticas que intervêm na estrutura física e, também, de outros instrumentos voltados para o urbano. Esta constatação não significa, entretanto, que a condição de vida da maior parcela da população que vive nas cidades tenha sido beneficiada pela execução de tais medidas. Isto porque a apropriação do que poderia ser um adicional de bem estar geral é feita de forma restrita, como que reproduzindo a apropriação concentrada da riqueza gerada pelo conjunto da população.

As áreas da cidade ocupadas por parcela da população melhor situada na escala de distribuição de renda normalmente são beneficiadas de forma cumulativa. Outra forma que a produção da cidade encontra para multiplicar suas possibilidades de continuar o processo de apropriação da maior parcela da renda urbana é a descontinuidade da ocupação, acelerando a horizontalidade e a heterogeneidade. Esses expedientes utilizados contribuem para a dispersão dos recursos públicos e para a sua insuficiência no suprimento das necessidades da população em geral.

Outro fator que pode ser considerado importante nesse processo é o fato da urbanização no Brasil ter se verificado principalmente pela saída do campo daquela parcela mais pobre da população que, além de não dispor de recursos para empreender uma atividade produtiva, também não está qualificada para se engajar em atividades urbanas que exijam maior treinamento e/ou qualificação, perpetuando-se assim a dificuldade de ascensão que, mesmo remotamente, lhe poderia ser propiciada. É, portanto, uma parcela da população com poucas possibilidades de ampliar a agregação de valor na economia, estando relegada a atividades de baixa produtividade. Sua absorção pelo meio urbano exigiria políticas globais de redistribuição de renda.

Por outro lado, essa população necessita e tem direito aos serviços básicos de saúde, educação, moradia, trabalho e tantos outros que lhe deveriam ser supridos pelo poder público. Ou seja, o fato de partirem de uma situação inicial de pobreza contribui para dificultar a função distributiva de benefícios pelo poder público, em face da precariedade de recursos governamentais em relação ao grande volume de necessidades que se tornam mais graves, considerando-se a baixa quantidade de riqueza agregada por essa camada da população. A grande transferência de recursos que deveria existir, mediada pelo estado, entre os segmentos da população mais rica para as mais pobres, esbarra em dificuldades postas por grupos políticamente organizados e com poderosa representatividade no Congresso Nacional. Desta forma, as opções de investimentos são definidas, de uma maneira geral, com a prevalência das forças com maior capacidade de articulação, quase sempre formadas pelas representações dos grupos melhor situados na escala socioeconômica.

\section{Intervenções Urbanas Durante os Governos Militares}

Os governos militares puderam constatar que dentre o grande número de problemas que poderiam trazer abalos à condução que pretenderam dar ao país estava o crescimento urbano. A preocupação com as cidades, como parte do contexto geral a ser trabalhado e conduzido, por serem os centros de consumo e locais de aglomeração de pessoas, da produção industrial, intelectual e de serviços, sobre os quais o controle poderia ser exercido de forma mais eficiente, levou os governos pós-1964 a se empenharem de forma contundente a dotá-las de instrumental convincente para as finalidades do crescimento proposto. 
A nova investida desenvolvimentista, além de aumentar a produtividade no campo, acenou com novas possibilidades ligadas à industrialização. A reestruturação do projeto de crescimento voltou-se intensamente para o urbano, sustentação das novas formas de acumulação então propostas. Entretanto, o meio urbano era também cenário para temíveis contestações, insatisfações que poderiam colocar sob risco toda a engenhosidade que se desenhava para alcançar o patamar dos países desenvolvidos.

Dessa forma, percebe-se o esforço imaginativo no sentido de dar às cidades as condições necessárias para atuarem sobre a demasiada deterioração das condições das populações pobres que já estavam urbanizadas, bem como da enorme quantidade de pessoas que, àquela época, se transferiam do campo para as cidades e mesmo entre cidades. A deterioração das cidades dificultaria a concretização dos projetos governamentais, pois, apesar do uso da força, os riscos de tensão seriam maiores e os controles poderiam se tornar mais difíceis. Além disso, havia necessidade de criação e ampliação de mercados para garantir a continuidade e o sucesso da industrialização.

É notório que os planos dos governos militares deram especial importância às questões urbanas, sendo que desde o PAEG (Plano de Ação Econômica do Governo) 1964/1967, Metas e Bases para o Planejamento, I PND, II PND, III PND (Planos Nacionais de Desenvolvimento), todos eles contemplaram substancialmente as questões urbanas desde a habitação, transporte urbano, normas para o planejamento urbano, estudos de viabilidade para atividades geradoras de empregos e implantação de distritos industriais. Foram criados os órgãos gestores dessas linhas de políticas públicas, em nível nacional, encarregados de acompanhar a elaboração dos projetos e a aplicação dos recursos destinados a esses fins.

Nessa fase, cabe ressaltar, houve uma grande centralização dos recursos orçamentários e/ou provenientes de empréstimos e financiamentos internacionais, no governo federal. Criou-se o Banco Nacional da Habitação (BNH), com recursos provenientes, em primeira instância, do Fundo de Garantia por Tempo de Serviço (FGTS) e também da Caderneta de Poupança, além de recursos internacionais, notadamente provenientes do Banco Mundial.
Essa foi a base para a definição de uma linha de intervenções urbanas com larga repercussão de caráter econômico-social, com grande eficácia por um período de tempo. A distribuição de recursos para intervenções nas cidades passava pelo órgão técnico ligado ao BNH - SERFHAU (Serviço Federal de Habitação e Urbanismo).

Foram instituídos os PDIs (Plano de Desenvolvimento Integrado), necessários para a alocação dos recursos disponíveis. Segundo as normas estabelecidas, os PDIs deveriam conter estudos que diagnosticassem os municípios no seu todo (zona urbana e rural) e propostas de medidas a serem tomadas pelos governos municipais que contemplassem os aspectos econômicos sociais e o tratamento do espaço físico, de forma a maximizar os investimentos a serem feitos, dando especial relevância às questões habitacionais. Essas questões, em princípio, estariam mais voltadas para o atendimento das populações que constituíam os segmentos de mais baixa renda.

Esses estudos puderam trazer à luz a atuação de escritórios que se formaram, projetando urbanistas nacionalmente, alguns dos quais criaram e reproduziram modelos de intervenções urbanas multiplicados em várias cidades brasileiras. Muitos desses profissionais ganharam notabilidade e ainda se encontram atuando na área do planejamento urbano.

Vale ressaltar que a política de formação e expansão de mercados no Brasil, no decorrer do século Xx, foi ancorada na implantação de cidades, como forma de propagar efeitos dinamizadores das atividades e interiorizar populações.

Sob esse aspecto, é interessante notar que o Brasil adotou como um dos seus eixos, de fundamental importância, a implantação de cidades (capitais de estados e Distrito Federal), como vetores de atração de população e dinamizadores dos espaços circunvizinhos.

Assim, em menos de um século, quatro capitais foram planejadas e implantadas, resultando na efetiva incorporação do interior, ao mercado nacional, e completando a integração do território: Belo Horizonte (capital de Minas Gerais, Goiânia (capital de Goiás), Brasília (Distrito Federal), e Palmas (capital do Tocantins). A implantação dessas cidades adensou regiões com baixa densidade demográfica e baixos padrões de produção e produtividade. 


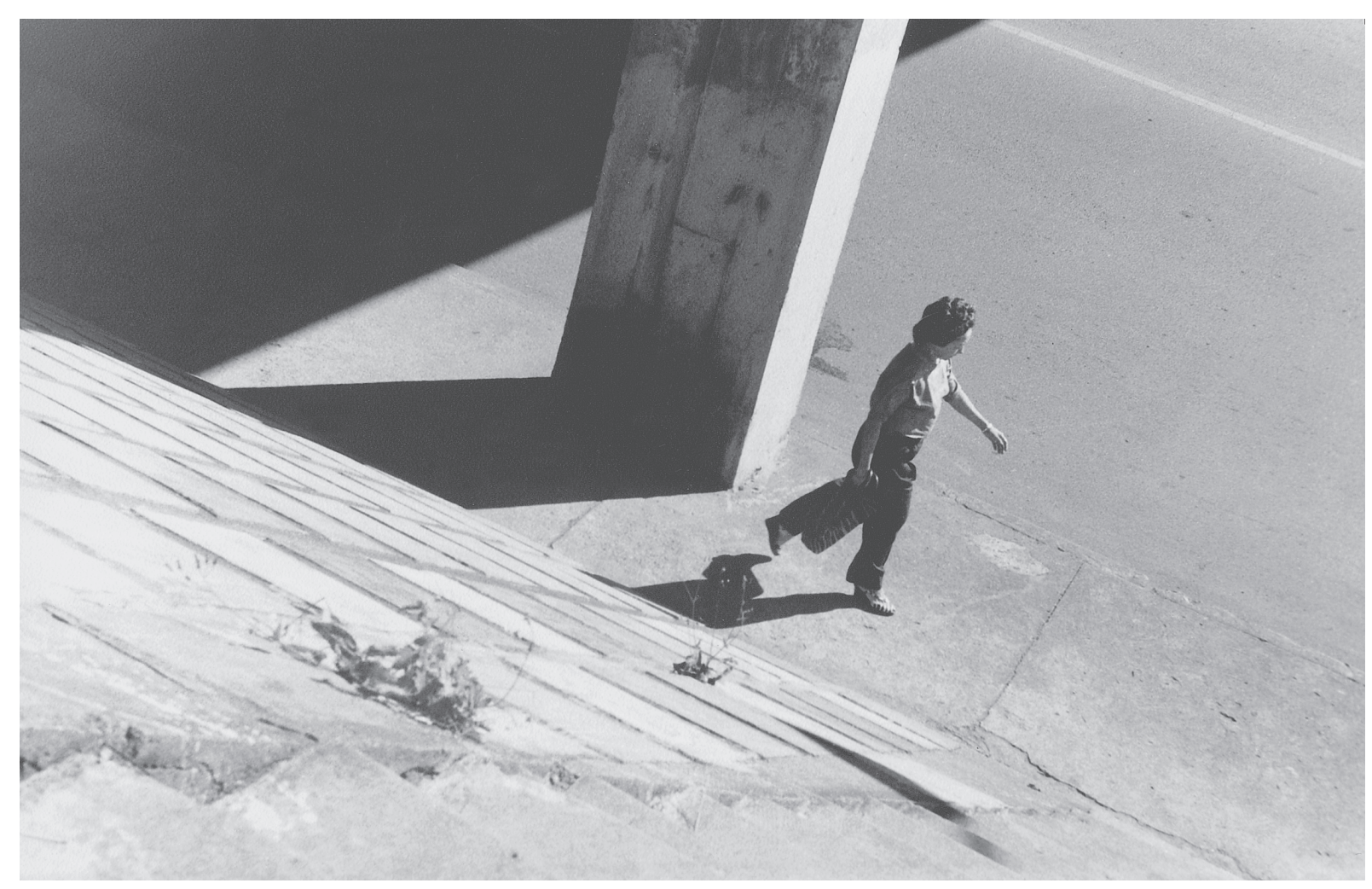

Brasília, 1998. Foto de Marcelo Feijó.

A urbanização crescente, as importações de automóveis, as influências européias, e americanas, apontaram para a necessidade de equipamentos urbanos até então prescindíveis e, já nas primeiras décadas do século $\mathrm{xx}$, cidades como o Rio de Janeiro e São Paulo passaram por interferências físicas no seu espaço de ocupação.

Mas foi durante o período desenvolvimentista - que se incia nos anos 30, mas tem o seu auge no pós-Segunda Guerra Mundial e se prolonga até final da década de 70 - com a industrialização e o afluxo de correntes migratórias campo-cidade, que o poder público passou a sofrer maiores pressões por políticas que melhor encaminhassem os problemas urbanos surgidos em decorrência do aumento da demanda por água tratada, energia elétrica, transporte coletivo, saúde, educação, habitação, imprescindíveis na vida moderna.

As dificuldades econômicas que se punham nos primeiros anos da década de 1960 colocaram em evidência a necessidade de esforços dirigidos às cidades, que assumiam o lugar de proeminência na produção. $\mathrm{O}$ modelo desenvolvimentista que fortaleceu a industrialização no Brasil através da substituição de importações ocorreu de forma predominante na região Sudeste, exacerbando a concentração das atividades e consequentemente da renda e da população para os estados que a constituíam.

A partir do pós-guerra, apesar da continuidade do processo de concentração espacial da população e da riqueza, a própria necessidade de expansão da produção e do consumo levou os governantes a desenvolverem políticas de interiorização que funcionaram como alavancadoras da forte urbanização, de forma mais generalizada. Esse processo de interiorização, além de todos os aspectos que possam ter contemplado, tentava também desconcentrar a população e a atividade produtiva por uma questão dos custos de urbanização, mas, de forma muito especial, pelos problemas econômicos, políticos e sociais que dali pudessem advir.

Assim, a própria transferência da capital da República para o interior foi decisiva na preparação de uma base para sustentação do desenvolvimento econômico. Essa interiorização foi devidamente incorporada pelos militares e incrementada pelos mesmos por meio de um programa de ocupação através de financiamentos, obras, e da tentativa de monitorar, de maneira centralizada, o encaminhamento do processo. 
A preocupação com o urbano está expressa desde o Programa de Ação Econômica do Governo (PAEG):1964-1967, através de uma política habitacional baseada na consciência do grande déficit habitacional, crescente a cada ano em decorrência da migração campo-cidade.

O problema é caracterizado pelo PAEG nos seguintes termos:

"O crescimento demográfico nas cidades processa-se de modo tumultuário, num ritmo médio de expansão de 63\% no decênio 1950/1960, desfigurou-lhes a fisionomia pela falta de planejamento e ordenação do desenvolvimento comunitário".

Esses fatores, conjugados a distorções de mercado geradas pela inflação, acumularam um déficit habitacional de graves proporções. Déficit quantitativo e qualitativo de moradias que, numa população de 75 milhões de habitantes, se cifra em 7 milhões de habitações. Isto equivale a afirmar que metade da população brasileira não conhece o conforto da habitação, segundo padrões mínimos desejáveis. Do total de moradias ora existentes, apenas preenchem condições de habitabilidade $25 \%$ das casas no Norte, $12 \%$ no Nordeste, $44 \%$ no Leste, $48 \%$ no Sul e $17 \%$ no Centro-Oeste"2.

As análises desenvolvidas pelo plano mostram como principais responsáveis pela situação, problemas que, desde a década de 1940, perturbam a economia brasileira e desencadearam um processo inflacionário que passou a empurrar a especulação imobiliária nos maiores centros, enquanto na maior parte do país permaneciam baixos os investimentos nessa área. A mesma análise vê a valorização dos terrenos, em decorrência da especulação e da pequena renda da maior parte da população, como causadora do afastamento da maior parcela da população urbana do mercado de imóveis para moradia.

Embora já houvesse o esboçar das idéias dos problemas urbanos, nesse primeiro programa governamental o tema restringe-se ao sistema habitacional, que é tratado separadamente da infra-estrutura urbana de saúde, saneamento, transporte etc. $\mathrm{O}$ encaminhamento da questão habitacional ainda não está muito definido, notadamente no seu aspecto crucial que é o financiamento. Fala-se na criação de um sistema de financiamento, mas sem detalhar de que forma o mesmo seria estruturado, nem tampouco as fontes abastecedoras de recursos ou linhas de crédito voltadas para essa finalidade.

O documento que veio a público em 1967, entretanto, o "Plano Decenal de Desenvolvimento Econômico e Social" elaborado pelo Ministério do Planejamento e Coordenação Econômica, traz as diretrizes gerais para a formulação de uma política de desenvolvimento regional e urbano.

A proposta de estabelecimento de uma política regional é ambiciosa, pois pretende diminuir as diferenças entre regiões aproveitando suas especialidades no sentido de torná-las autônomas, considerando como tal suas possibilidades de manterem um crescimento auto-sustentável. É interessante notar que há uma recorrência no que seria a teoria das vantagens comparativas ricardianas, que tem sido a base de todo o planejamento, tal como tem sido estudado e aplicado, de uma maneira geral. A proposta dessa época é a de aproveitar potencialidades locais, dotar as regiões de infra-estrutura econômico-social e, através do próprio processo de implantação das obras, pessoas para trabalhar e investidores, para o preenchimento dos vazios, principalmente das regiões Centro-Oeste, Norte e Nordeste.

A política de desenvolvimento urbano que se propunha acompanhava o ideário da regional, na medida em que, além de se pretender preventiva, de acordo com as propostas de acelerar a ocupação em determinadas regiões, também objetivava preterir uma excessiva concentração que se esboçava, notadamente na região Sudeste e nas metrópoles do Rio de Janeiro e São Paulo.

Os argumentos levantados no trabalho conduzem no sentido de mostrar uma tendência à concentração, uma vez que, entre 1950 e 1960, o maior crescimento populacional foi verificado nas cidades com mais de 100000 habitantes. Essas cidades, em 1950, detinham $13,1 \%$ da população e, em 1960, 18,8\%. Vale ressaltar também que essas cidades, que constituíam $4,2 \%$ do total de cidades entre 1940-1950, passaram a 6,09\% no período de 1950-1960, crescimento que só foi superado, na mesma fase, pelas cidades de mais de 20000 habitantes (MPCE 1967:100).

$\mathrm{O}$ que se pode perceber também é que havia a preocupação com a concentração exacerbada nas principais metrópoles da América Latina, como o

\footnotetext{
${ }^{2}$ Programa de Ação Econômica do Governo: 1964-1966, Vol. I - Objetivos e Instrumentos de Ação (Redação Preliminar).XIII-1.
} 


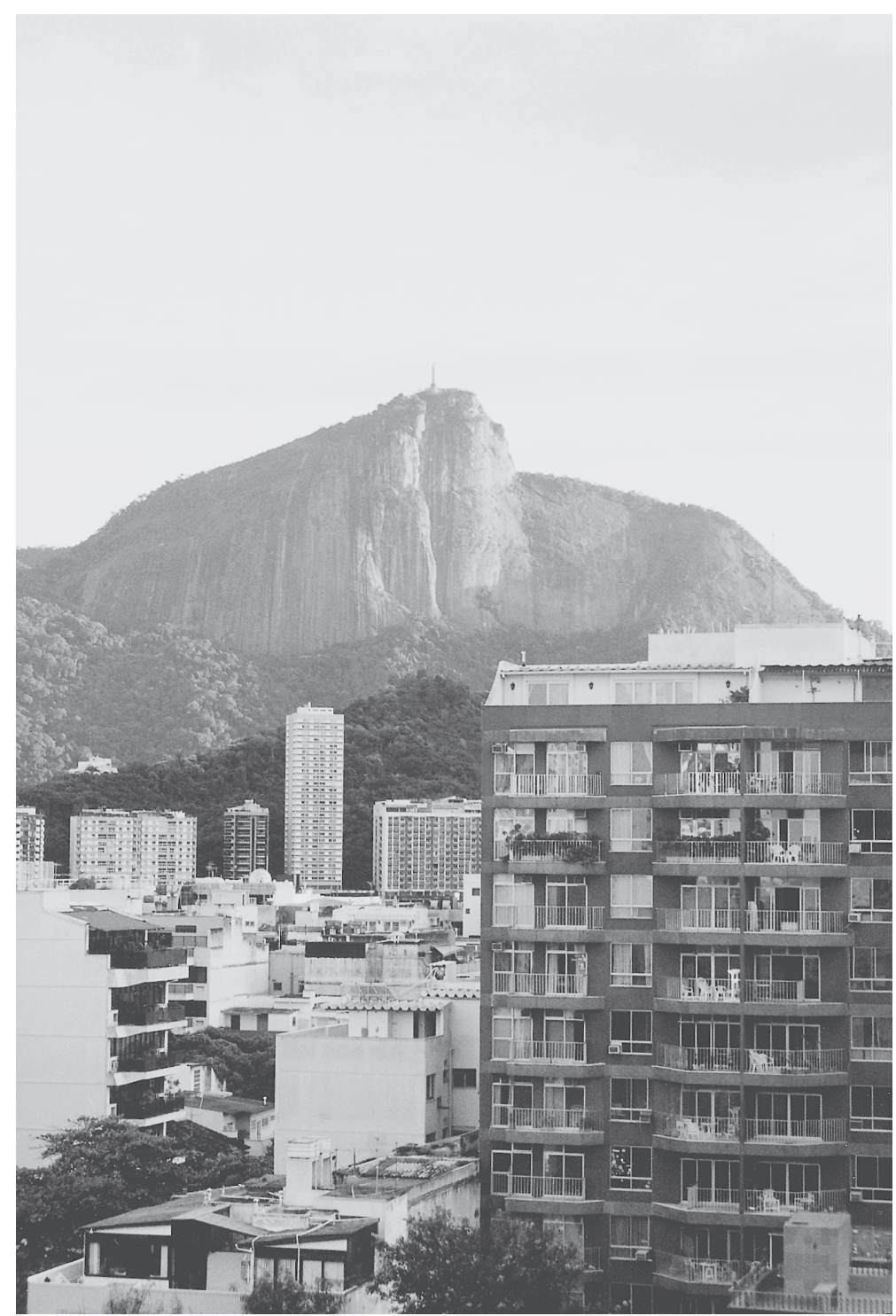

Rio de Janeiro. Foto de Vítor Matias Ferreira.

caso de Buenos Aires, que concentrava 35\% da população Argentina e Caracas, com 21,1\% da população venezuelana (Idem: 102).

Por outro lado, deve-se considerar a influência inglesa, americana e francesa, no que se refere às propostas e tentativas de desconcentração demográfica. Os elaboradores do Plano Decenal de Desenvolvimento Econômico e Social (1967) levaram em consideração esses modelos como inspiradores do que poderia ser um conjunto de políticas públicas capaz de levar a uma distribuição da população e das atividades econômicas propiciadoras de bem estar e apaziguadoras de tensões.

A análise desses modelos mostrava o esvaziamento dos centros urbanos com população superior a 100000 habitantes. Alcançar esse objetivo significava dispor de um conjunto de instrumentos capazes de "disciplinar o crescimento urbano".

"A criação das cidades novas, algumas das quais já haviam surgido no famoso Plano da Grande Londres (1946), foi também consequência das medidas adotadas naquele período. Todas as cidades e condados foram obrigados a elaborar planos de desenvolvimento, exigindo-se, inclusive, a revisão quinquenal dos planos elaborados. Promoveram-se ainda cursos intensivos para treinamento de técnicos" (Idem:105).

No que se refere aos Estados Unidos, "as políticas nacionais nos setores habitacionais e do planejamento urbano foram e ainda são as principais responsáveis pelo início do processo de descongestionamento dos grandes centros 
urbanos.(...) Pode afirmar-se, ainda, que tal fenómeno de descongestionamento dos centros metropolitanos, embora menos acentuado do que no caso da Inglaterra, se originou também em nível local, através de leis de zoneamento e de planejamento urbano em geral" (Idem: 106-7). "O V Plano Francês é outro exemplo de política nacional de redistribuição da população urbana. Buscar-se-á descongestionar Paris através do desenvolvimento de 8 metrópoles regionais, chamadas metrópoles de equilíbrio. Neste caso, porém, ainda não houve tempo para se avaliarem os resultados" (Idem: 107).

Esse conjunto de idéias e realizações alimenta os planejadores para um esquema que tentava fazer uma ligação entre regional e urbano. Não se pode negar a influência do projeto americano, quando se constata a ligação entre as questões habitacionais e urbanas. No caso brasileiro, mais um fator pressionava em direção a essa fórmula, que era o fato da urbanização estar se fazendo com grande parcela da população com precária qualificação.

Sendo a construção civil, no caso brasileiro, muito dinâmica e largamente empregadora de mão-de-obra com baixa qualificação, tornava-se muito oportuno empreender esse caminho. As condições para as propostas eram especiais, pois as formulações tinham a facilidade de não encontrarem negativas ou reivindicações específicas por parte de grupos opositores ou de representação popular, sendo, portanto, as propostas facilmente transformadas em determinações às quais os estados $\mathrm{e}$ municípios estavam sujeitos.

$\mathrm{O}$ temor às grandes aglomerações e aos problemas causados pelas mesmas, e que poderiam fugir ao controle governamental, se somam às argumentações acerca dos altos custos para sustentar o chamado "crescimento caótico" das cidades, justificando uma política urbana que conseguiu, pelo menos no final da década de 60 , toda a década de 70 e primeiros anos da década de 80, se impor como um padrão que deveria ser seguido indiscriminadamente por todos os municípios brasileiros, tornando-o, portanto, discriminatório.

A implantação de uma política urbana que teve como carro-chefe a habitação trouxe inúmeros problemas, decorrentes não só do sistema político centralizador, sem opositores e sem interlocução popular, mas também do aparato tecno-burocrático encarregado do desdobramento das diretrizes em projetos específicos e da execução dos mesmos.
A falta de pessoal que detivesse a tecnologia da elaboração dos projetos nas prefeituras levou à formação de escritórios de profissionais que se anteciparam na apreensão das novas exigências a serem cumpridas para se ter acesso aos financiamentos para a execução de obras. Esses escritórios tratavam de reproduzir e vender os modelos que deram certo em alguns municípios, independentemente (ou quase) das características que diferenciavam as várias cidades. Assim, o que se pode considerar como uma proposta autoritária, numa fase de exceção, generalizava-se através de grupos interdisciplinares de profissionais.

O desenvolvimentismo, ou, como querem alguns teóricos, a expansão do fordismo para a periferia do mundo capitalista, induzindo à massificação da produção e do consumo, foi a fase de mais intenso crescimento econômico do Brasil no século $\mathrm{Xx}$ e coincide com o mais intenso das políticas urbanas, no sentido de sua generalização. Entretanto, vale indagar em que medida a saída dos militares do poder e a mudança nos padrões de acumulação, que agora pendem para a flexibilização, colocaram novos instrumentos de política urbana.

\section{A Força da Cidade e das Metrópoles}

O aumento da urbanização, a partir da segunda metade do século Xx, foi particularmente grande no Brasil, multiplicando-se as cidades com população acima de um milhão de habitantes. $\mathrm{O}$ afluxo de pessoas para a zona urbana tem motivos das mais diversas ordens, que vão desde as dificuldades que os avanços da tecnologia trouxeram aos mais pobres que moravam e produziam no campo, à transferência de pessoas entre cidades, buscando maior participação das conquistas obtidas pelo conjunto da sociedade.

A absorção das pessoas que chegam às cidades é rigorosamente seletiva, e a melhor acolhida é para os que trazem melhores condições para essa inserção no que se refere à posse de recursos financeiros e de bens e/ou melhor preparo educacional, o que os credencia a melhor situar-se perante o mercado de trabalho.

Dessa forma, a cidade credencia melhor aqueles que já partem de um patamar mais alto de propriedade, de bens materiais e educação formal. Os migrantes juntam-se à população local e 


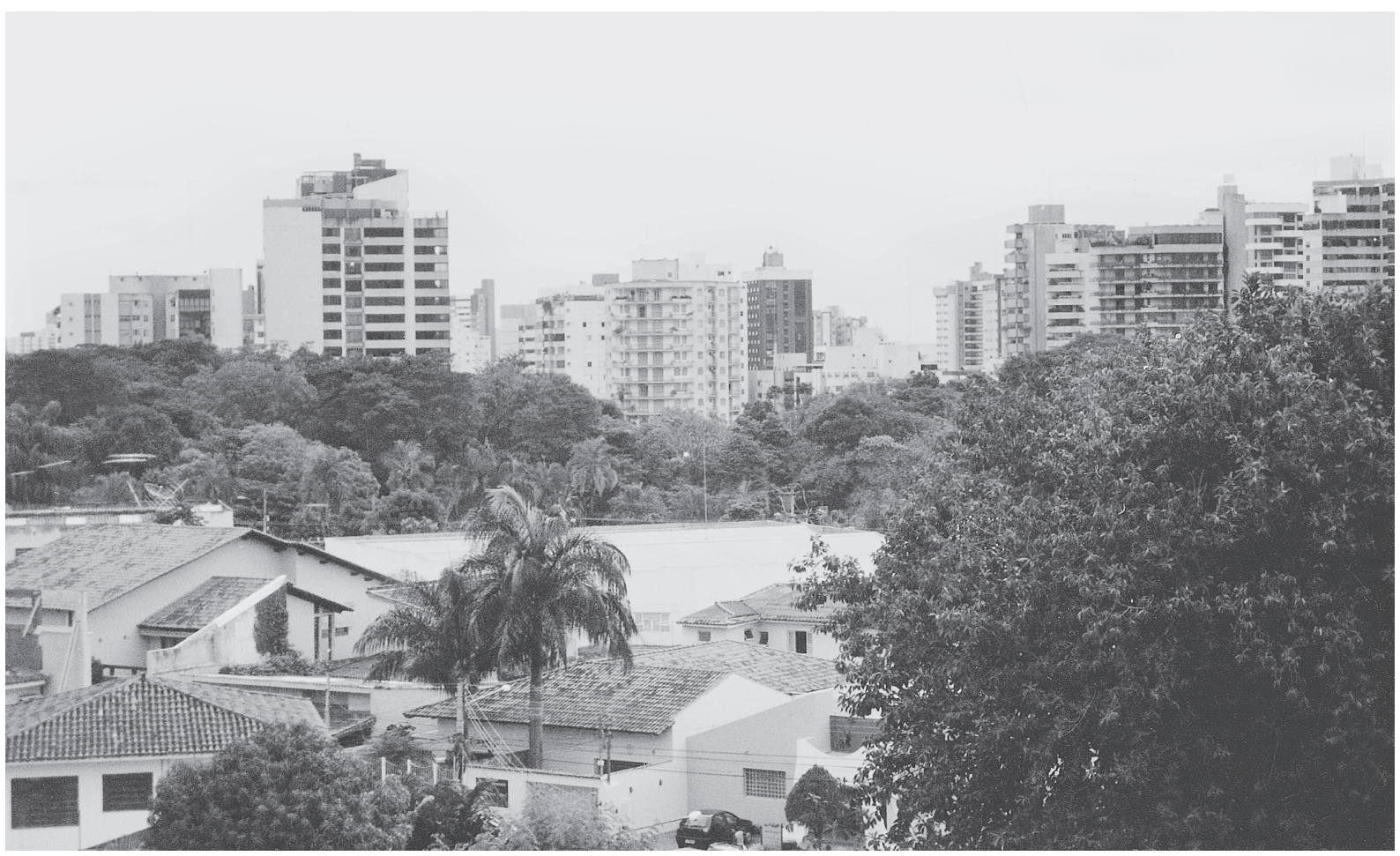

Goiânia, Estado de Goiás. Foto de Vítor Matias Ferreira.

enquadram-se nesse esquema que está estabelecido no meio urbano.

A solicitação dos serviços urbanos por parte da população urbana em geral é tendencialmente crescente. E o crescimento é muito mais intenso por parte dessa população que agrega menos valor à cidade, embora, pela sua dimensão, se constitua em importante fonte de recursos arrecadados pelo poder público .

De qualquer forma, a demanda por serviços é sempre muito maior que a oferta dos mesmos e é um problema largamente agravado pela ação daquele segmento que explora a produção imobiliária e o comércio do solo urbano. Esses agentes econômico-sociais tratam de colaborar para elevar os custos urbanos, expandindo as fronteiras das cidades pela incorporação de terrenos de mais baixo preço, antes que todo o espaço urbano seja ocupado.

Essa expansão traz uma série de problemas que vão desde o dificultar o acesso das pessoas aos seus postos de trabalho, à diminuição da produtividade da infra-estrutura que, ao se alongar, o faz de maneira a cobrir áreas muito esparsamente habitadas ou mesmo vazias.

Essa mudança na vida do homem introduziu comportamentos individuais e sociais característicos dessa nova situação, muito mais segmentada não só no que se refere aos locais de morar, de trabalhar, de lazer, como sob o aspecto das diferentes participações na apropriação da riqueza gerada. A diversidade passa a ser, portanto, uma das fortes características do que constitui a cidade. Essa diversidade, como não poderia deixar de ser, passa a ser o ponto fundamental dos conflitos, exigindo dos governantes a mediação no sentido de amenizá-los ou mesmo apaziguá-los.

Esse aumento de custo para o poder público é, em primeira instância, apropriado pelo proprietário da terra urbana ou (e principalmente) pelo empreendedor imobiliário e, residualmente, ao que se torna proprietário, quase sempre no sistema de compra com muitos anos para realizar o pagamento, o que o mantém vulnerável durante uma grande parte do seu tempo útil de vida. Além de suprir esses locais mais distantes com infra-estrutura física de água, energia elétrica, esgoto, asfalto, há ainda necessidades ligadas à saúde, educação e tantas outras que a cidade impõe aos indivíduos.

O caso de Goiânia é dos mais relevantes em razão das altas taxas de crescimento populacional, notadamente nas décadas de 50/60 e 60/70, auge da implantação de Brasília e de grandes investimentos na região, grandes obras e a implantação de serviços para dar sustentação ao processo de crescimento a uma grande parte do Centro Oeste. 
Em geral, os altos custos da cidade e a fraca organização da população requerem muito maior conhecimento e acompanhamento por parte das várias instâncias de governo, para um melhor conhecimento dos problemas gerais das cidades e suas regiões metropolitanas, como também dos problemas localizados e que estão essencialmente nos pontos de assentamento das populações mais pobres.

Neste sentido as metrópoles assumem, em todo o mundo, e particularmente no Brasil, um papel fundamental não só como centros que concentram as decisões sobre os destinos da economia, como também abrigam a problemática da população integrada e não integrada ao processo de crescimento. Tomar conhecimento de como esses processos acontecem e detectar quais os seus fundamentos tem sido preocupação dos gestores públicos dessas cidades, mas também de teóricos e estudiosos da academia, nas mais diversas áreas de conhecimento.

As metodologias empregadas para diagnosticar os problemas mais centrais têm sido desenvolvidas por diversos grupos interessados no desenvolvimento social, político, econômico, para a melhoria das condições de vida da população. Dentre os diversos esforços empreendidos pelos governos, juntamente com a academia, está o que procura detectar a espacialização da população, de acordo com indicadores que atribuem condições de usufruir, ou não, dos serviços públicos, resultado do esforço conjunto, mas apropriado de forma extremamente desigual.

A grande onda desenvolvimentista que entrou em crise nos últimos anos da década de 70 deu lugar à chegada de uma proposta de mudança no padrão de acumulação, introduzindo a flexibilização não só nas relações de trabalho, mas também na administração do Estado, que muda as formas de regular a economia e passa a ser mais pressionado pelas demandas sociais.

As tentativas de ajuste da economia, a contenção da inflação, o endividamento do Estado e as necessidades impostas pelo mercado de qualidade e preços competitivos levaram à adoção de políticas liberais. Os esforços para alcançar o equilíbrio fiscal implicam, naturalmente, na diminuição dos dispêndios governamentais.

Assim, o quadro que se forma é amplamente desfavorável ao trabalho, pois além de todos esses fatores, o grande avanço tecnológico diminuiu o número de empregos e distanciou, em razão da baixa qualificação, os novos postos criados, da mão-de-obra disponível no mercado. Tem-se, dessa forma, um mercado de trabalho que encolhe, em decorrência do avanço tecnológico e da retração dos gastos públicos, e, além disso, as remunerações entram em queda, o que se reflete em maiores dificuldades para a maior parte da população.

A necessidade de diminuir custos das empresas, para se tornarem competitivas no mercado interno e internacional, resultou no aprofundamento do uso de contratos de trabalho que suprimem ou diminuem os benefícios sociais adquiridos pelos trabalhadores. Os quadros de empregados fixos diminuem e aumentam os temporários, terceirizados, autônomos e/ou informais.

A gestão governamental faz um movimento tentando incorporar novas variáveis, para gerir a expansão do desemprego e todas as conseqüências que a situação acarreta para a vida urbana, mas o mercado opera de forma restritiva, frustrando muitas das expectativas despertadas.

Nesse contexto, as políticas também se tornam fragmentadas, embora dirigidas a um mesmo espaço administrativo, seja estado ou município, mas com vinculações profundas com a administração central, até pela dependência de recursos financeiros. Assim, estados e municípios executam as políticas traçadas pela administração federal, mas com margens de recursos próprios que permitem políticas localizadas. O raciocínio que conduz à expansão econômica aponta no sentido de uma política que é o de ampliação das atividades ligadas ao capital privado que se instala trazendo investimentos, inovações tecnológicas, aumento da produtividade, aumento de exportações, e, logicamente, aumenta o peso político daquelas localidades que lhe facilitam novos benefícios nas áreas federal, estadual e municipal.

A unidade espacial que reflete esse processo é a cidade, e todo o urbano é afetado quando o mesmo se verifica de forma ascendente ou quando, em situação adversa, há um ciclo de contração de todos os fatores enumerados.

Diante de um quadro que afeta a economia e se reflete na arrecadação pública, as pressões funcionam como alavancadoras de políticas voltadas para a geração de emprego e renda, bem como inviabilizam a contenção da informalidade, 
levando os administradores públicos a uma constante necessidade de conciliar o uso do espaço das cidades entre os que transitam rotineiramente e os que usam esse espaço, que é público, para desenvolver suas atividades produtivas. Além disso, existe o conflito entre os produtores e os comerciantes que têm suas atividades exercidas segundo as normas vigentes, que se julgam prejudicados por aqueles que não têm os mesmos ônus e participam da produção e da comercialização concorrentemente.

Se o esgotamento do modelo desenvolvimentista trouxe de volta as idéias e políticas liberais, provocando perplexidades nas atitudes governamentais, também é verdade que a crise que se instalou conduziu a novas propostas, ainda que não se possa saber, de forma mais próxima, quais os caminhos, dos muitos que se apresentam, trarão maiores satisfações a tantas demandas existentes nas cidades.

A diminuição dos recursos públicos o crescimento do número de grandes cidades conduz a um maior número de alternativas de políticas urbanas, oportunizando não só maior organização da sociedade civil, como a solicitação de maior participação dos setores produtivos para o cumprimento de tarefas, antes de exclusiva competência do Estado. Há uma tendência à formação de parcerias entre o o poder público e as Organizações não Governamentais (ONGs), que captam recuros, também externos, e outros tipos de arranjos entre diversas instuições como as igrejas, que respaldam grupos de voluntariado que trabalham para a formação de associações e cooperativas de pequenos produtores e prestadores de serviços, visando integrar parcelas da população mais pobre e com menores possibilidades de absorção pelo mercado de trabalho. Merece especial destaque a política de microcrédito, que é uma política de caráter internacional, com a finalidade de autonomizar desempregados. Essas redes, além de terem uma função de cunho socioeconômico, na medida em que possibilitam o acesso das camadas mais pobres a atividades geradoras de renda, integrando-as ao mercado consumidor, podem contribuir para o estabelecimento de uma relação de maior peso com os poderes governa- mentais. Por um lado, os liberam de algumas pressões, próprias dos que não têm renda. Por outro podem se constituir em grupos com maior força nas decisões de políticas urbanas.

Esse é um momento que se diferencia daquele vivido no desenvolvimentismo, no que se refere às políticas urbanas, quando os interesses governamentais estavam voltados para a consolidação da ocupação do território e a implantação da infra-estrutura mais essencial às cidades e regiões. Certamente isso não aconteceu de forma equânime, mas atendeu, de forma muito mais generosa às regiões/cidades concentradoras de maior poder político/económico, mantendo assim as assimetrias que caracterizam a distribuição espacial e funcional da riqueza no Brasil, desde épocas mais remotas.

\section{Novas Políticas Urbanas: as diferentes concepções}

A intensificação da metropolização dos espaços urbanos no Brasil, trouxe consequências conhecidas: de um lado, o aumento da demanda superior à oferta por moradia, saúde, educação, trabalho e, de outro, mais que proporcionalmente, o aumento do desemprego e da criminalidade, atingindo principalmente os jovens, o aumento da corrupção passiva e ativa, em função da impunidade e da falta de oportunidades de trabalho, e o fortalecimento do crime organizado, poder que se coloca paralelo às instituições públicas, desacreditando a frágil democracia brasileira reconquistada pelo povo no início dos anos 80.

Paralelo a esse quadro caótico, ou talvez até por conta dele ou ainda como uma resposta da sociedade, sobretudo dos setores organizados, inicia-se a construção de um novo ambiente que possibilita a formulação de novas políticas urbanas. Cabe ressaltar que esse novo ambiente não se refere aos gabinetes refrigerados onde historicamente se elaborou grande parte das políticas públicas, em especial, as políticas urbanas. Pelo contrário, esse novo ambiente foi gestado nas ruas, em assembléias, abaixo-assinados, ou seja, é fruto de mobilizações que tinham vários objetivos, dentre os quais, o de promover a reforma urbana no Brasil ${ }^{3}$.

\footnotetext{
${ }^{3}$ Dentre as grandes bandeiras reformistas no Brasil, a Reforma Agrária é de fato a que mais movimentou e ainda movimenta os setores organizados no campo. É uma luta histórica que avança lentamente, mas que ainda não produziu os resultados que se esperavam, e não conseguiu sensibilizar a grande maioria de deserdados urbanos, de modo a incorporá-los massivamente nesta luta, apesar de o Movimento dos Trabalhadores Sem Terra (MST) ter como uma de suas estratégias, buscar militantes nas periferias das grandes e médias cidades brasileiras.
} 
Sendo assim, a reforma urbana avança com a Constituição Federal de 1988. Os constituintes, pressionados por segmentos da sociedade civil organizada, incorporaram ao texto constitucional contribuições que constam no Capítulo II - Da Política Urbana, composto por dois importantes artigos, quais sejam:

Art. 182 - "A política de desenvolvimento urbano, executada pelo Poder Público municipal, conforme diretrizes gerais fixadas em lei, tem por objetivo ordenar o pleno desenvolvimento das funções sociais da cidade e garantir o bem-estar de seus habitantes".

Art. 183 - "Aquele que possuir como sua área urbana de até duzentos e cinquenta metros quadrados, por cinco anos, ininterruptamente e sem oposição, utilizando-a para sua moradia ou de sua família, adquirir-lhe-á o domínio, desde que não seja proprietário de outro imóvel urbano ou rural".

Ambos os artigos foram regulamentados pela Lei n. ${ }^{\circ} 10$ 257, de 10/07/2001, a Lei do Estatuto da Cidade. Os parágrafos e os incisos do artigo 182 implicam, a médio e longo prazo, em alterações na estrutura fundiária urbana. Dentre esses, destaca-se o parágrafo $4 .^{\circ}$ e seus incisos, que diz o seguinte:

"Parágrafo 4. ${ }^{\circ}$ - É facultado ao Poder Público municipal, mediante lei específica para área incluída no plano diretor, exigir, nos termos da lei federal, do proprietário do solo urbano não edificado, subutilizado ou não utilizado, que promova seu adequado aproveitamento, sob pena, sucessivamente, de:

"I - parcelamento ou edificação compulsórios;

"II - imposto sobre a propriedade predial e territorial urbana progressivo no tempo;

"III - desapropriação com pagamento mediante títulos da dívida pública de emissão previamente aprovada pelo Senado Federal, com prazo de resgate de até dez anos, em parcelas anuais, iguais e sucessivas, assegurados o valor real da indenização e os juros legais."

O fato da Constituição Federal incorporar esses artigos não significou que essa batalha estava ganha. Trouxe um grande alento à luta por uma cidade mais justa, porém a luta pela sua regulamentação se estendeu por mais 12 (doze) anos de articulações junto aos deputados e senadores federais e também junto à Presidência da República. Isto significa que os instrumentos de política urbana previstos na Constituição
Brasileira de 1988 não puderam ser aplicados. Nas cidades onde se tentou, a elite contrária encarregou-se de articular sua inelegibilidade, alegando ser inconstitucional sua implementação, uma vez que os referidos artigos ainda não haviam sido regulamentados. Como se diz no Brasil, "era o cachorro correndo atrás do próprio rabo", ou seja, não se regulamentava porque os políticos representantes das elites no Congresso Nacional não permitiam, e os gestores públicos, pressionados pelo capital imobiliário, não implementavam porque o Congresso Nacional não havia regulamentado.

Enfim, 12 anos após a aprovação da Constituição Brasileira, os Art.s 182 e 183 foram regulamentados através do Estatuto da Cidade. Desde então, todos os municípios brasileiros dispõem de instrumentos importantes de gestão urbana. Alguns já estão ajustando suas legislações urbanísticas visando a sua implementação.

\section{Contexto Global}

$\mathrm{O}$ contexto mais forte que marca as políticas urbanas nos anos 90 está relacionado às transformações econômicas que vêm ocorrendo no Brasil no padrão de acumulação de capital desde meados dos anos 80, transformações essas que se iniciaram nos anos 70 nos países centrais e, como consequência, o impacto dessas transformações sobre o espaço urbano. Se, por um lado, as mudanças no âmbito da economia têm exercido pressões significativas sobre os instrumentos tradicionais de planejamento urbano, por outro, essas mesmas pressões tem possibilitado aos municípios buscarem formas alternativas de desenvolvimento urbano e desenvolvimento econômico local.

No que se refere às mudanças econômicas, cabe perguntar: quais são os tipos de pressão que a "nova economia" exerce sobre as cidades? Pode-se responder que as exigências das empresas, para se instalarem nas cidades, consideram como fundamentais não mais os requisitos tradicionais como a existência de mão-de-obra barata, mesmo desqualificada, e a abundância de matéria prima. As empresas de qualquer ramo produtivo estão demandando outros requisitos, além de competitividade, localização privilegiada, e mão-de-obra qualificada, a isenção de impostos. Esses pré- 


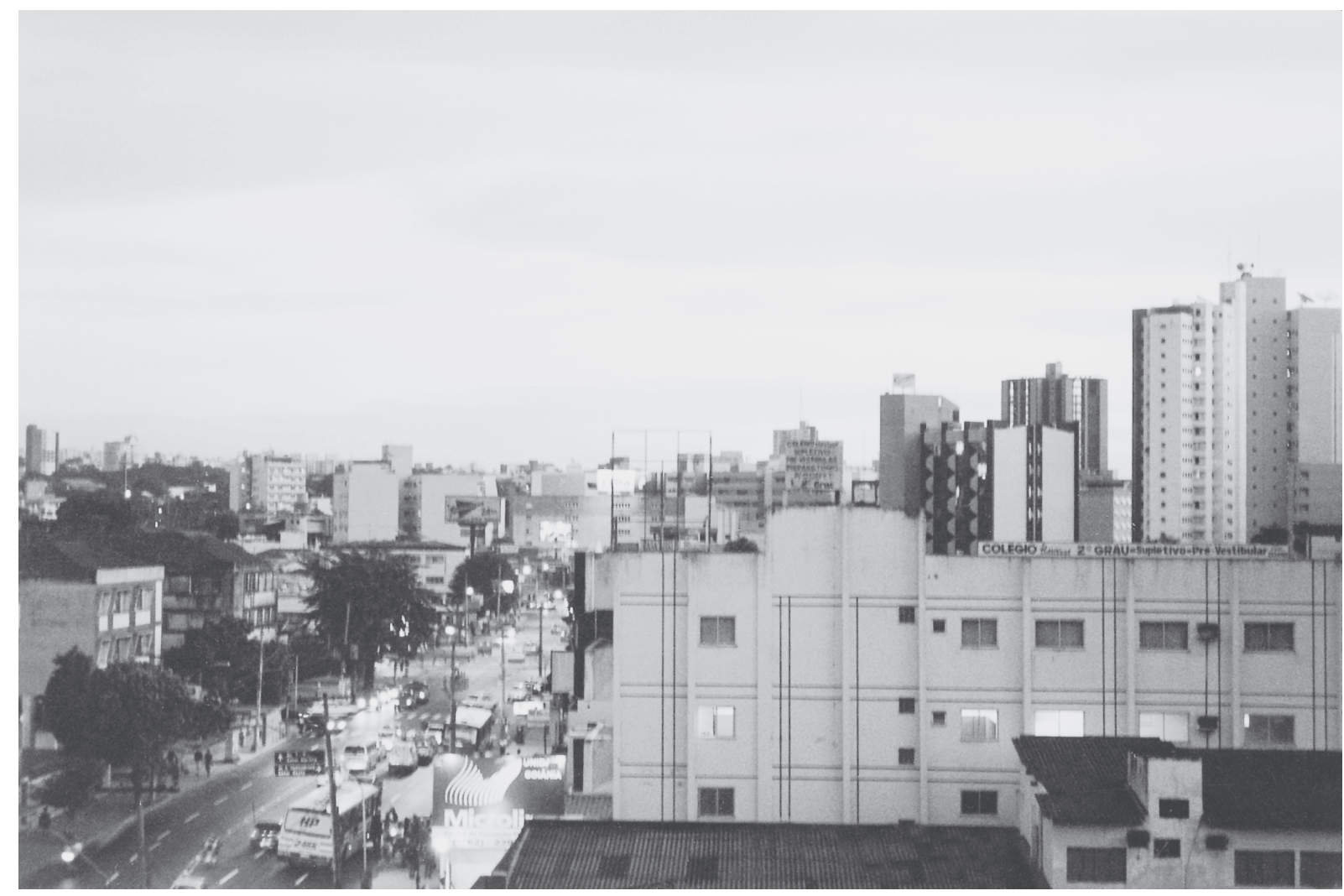

Goiânia/ Estado de Goiás. Foto de Vítor Matias Ferreira.

-requisitos são seguidos por um processo de ingerência sobre o espaço urbano que implica alterações significativas sobre os instrumentos de planejamento urbano, substituindo, por exemplo, os tradicionais Planos Diretores, que passam a se denominar Planos Estratégicos.

Em linhas gerais, o objetivo dos Planos Estratégicos é estruturar a sociedade urbana para o mundo globalizado. Por isso, recomendam o ajuste das cidades à nova economia, o que exige por parte do poder público a intensificação de mecanismos para atrair o grande capital. Para isso o papel do Estado é central, pois cabe a ele fazer concessões, ordenar territorialmente a cidade e, através de uma estratégia de city marketing arrojado, vender a cidade e potencializar os investimentos públicos e privados. Neste contexto, as cidades são vistas como mercadorias que precisam ser eficientemente colocadas no mercado ${ }^{4}$.

Nesta perspectiva, a construção do espaço urbano passa a ser orientada pelo que a literatura internacional denomina de Large-Scale Urban Development Projects, ou UDPs - Projetos de De- senvolvimento Urbano de Larga Escala. Os grandes projetos estão presentes nas médias e grandes cidades do mundo e cada vez mais interferem no ordenamento das cidades.

Esta tendência remete a outra questão: o que os gestores das cidades têm feito visando atender às exigências do novo padrão de acumulação de capital para se instalarem em seus respectivos territórios?

Os objetivos centrais da acumulação capitalista não mudaram, mas deve-se considerar que, a partir dos anos 70 nos países centrais e de meados dos 80 e anos 90 no Brasil, o perfil produtivo e organizacional das empresas se transformou, e as cidades, por sua vez, se vêm obrigadas a adotar estratégias de subordinação às exigências desse novo padrão. A consequência imediata das transformações econômicas sobre as cidades é que elas tiveram que ajustar seus instrumentos de planejamento urbano, num primeiro momento, para manter as empresas que já estão instaladas no município e, num segundo momento, atrair novas empresas na perspectiva de

\footnotetext{
${ }^{4}$ Para uma discussão mais aprofundada sobre o Plano Estratégico, numa visão crítica, sugiro consultar Vainer (2000), Sanchez (1999).
} 
manter e/ou ampliar os níveis de emprego e de investimentos.

Assim como o processo de acumulação resulta de um processo incessante de concorrência acirrada entre as unidades produtivas, as cidades também têm de se reestruturar para se tornarem, ao mesmo tempo, competitivas e um espaço de valorização do capital. Em outros termos, o processo de intervenção do poder público também se moderniza e se reestrutura. No dizer de Porto (2001:15), os administradores públicos "devem descobrir e realçar as potencialidades de seus municípios, bem como corrigir eventuais defeitos de sua estrutura local, com o objetivo de se criarem oportunidades para o capital se valorizar naquela cidade".

$\mathrm{Na}$ nova economia, os administradores públicos estão se transformando em gerentes de cidades. Revestidos dessa nova função, cabe a eles transformar as cidades em espaço de competição, razão pela qual cada vez mais instrumentos como o marketing de cidades, o planejamento estratégico e o urbanismo-espetáculo (Motta, 2001:15) se constituem em ferramentas indispensáveis.

$\mathrm{O}$ Brasil não foge às exigências dessa nova economia. Por aqui também o grande capital faz suas investidas na busca de novos espaços de investimentos com possibilidades elevadas de retorno. Considerando que o Estado brasileiro vem-se fragilizando de forma crescente a partir dos anos 80 e, portanto, no dizer de Cano (1993: 35), acha-se "desorganizado" e muito pouco "defensivo", esta condição coloca o país numa "saia curta e justa" que o impede de se impor e mudar as regras do jogo a seu favor.

No plano estadual e municipal, muitos dos gestores públicos nem sequer se assumem na condição de gerentes de suas localidades e acabam se transformando em agentes do empreendedorismo privado. Valendo-se da fragilidade ou até da ausência de políticas tributárias locais, franqueiam seus municípios às investidas do capital, muitas vezes sem nem sequer se aterem às manobras que visam tão somente maximizar o retorno dos investimentos feitos.

Neste sentido, a maioria dos municípios brasileiros, sobretudo aqueles que oferecem vantagens comparativas, como é o caso das médias e grandes cidades dotadas com o mínimo de infra-estrutura física e social, acabam se tornando reféns do grande capital. É precisamente nessas cidades que as grandes plantas industriais, comerciais e de serviços, modernizadas, exercem sua pressão, criando uma rede de apoio ao grande capital que inclui políticos, empresários e setores dos governos estaduais e locais.

As experiências inovadoras de gestão das cidades não deixam de ser uma tentativa de se contrapor ao poder do grande capital. Essa questão será abordada mais adiante.

\section{Contexto Social Nacional}

No Brasil, nos últimos trinta anos, os problemas sociais, na perspectiva de sua superação, não têm merecido a atenção necessária em função de opções que foram feitas com vistas ao ajustamento da economia. Na década de 90, em virtude da crise do Estado Desenvolvimentista consolidada na década de 80 da desregulamentação da economia e do perverso desmonte do Estado-Providência, as desigualdades sociais acentuaram-se, sobretudo em função da redução de postos de trabalho imposta pelo modelo económico hegemónico que faz crescer o contingente dos aptos ao trabalho para um mercado sem-trabalho. O Banco Mundial reconhece que o Brasil é uma das nações mais injustas do mundo. Para ele, "o nível de pobreza no Brasil está muito acima da norma para um país de rendimento médio". Entretanto, admite que "seria possível eliminar a pobreza no Brasil (concedendo a cada pobre o dinheiro suficiente para elevá-lo até o limiar da pobreza) por um custo inferior a $1 \%$ do produto interno bruto do país" (citado em Souza, 2002: 459).

A taxa de desemprego no Brasil, medida oficialmente pelo IBGE - Instituto Brasileiro de Geografia e Estatística - nas nove principais Regiões Metropolitanas no final de 2002, gira em torno dos 10\%, e o DIEESE - Departamento Intersindical de Estatística e Estudos Socioeconômicos -, com metodologia diferente, contabiliza para a grande São Paulo quase $20 \%$ de trabalhadores desempregados. Mesmo para os que permanecem no mercado de trabalho as condições de precarização são enormes, pois convivem com jornada de trabalho mais longas, salários com tendência a decrescer e menores garantias sociais.

Todo esse processo, gerador de uma nova forma de exclusão social, se insere num contexto internacional em que as políticas econômicas são 
de corte neoliberal, o que implica, para os países em desenvolvimento, uma inserção submissa no mundo globalizado. O país tem estado mais voltado para a correção dos desequilíbrios de caráter conjuntural, portanto de curto prazo, através de programas de ajustamento da economia, em detrimento de uma política desenvolvimentista de longo prazo, promovida por um Estado estruturante, como foi visto anteriormente $\mathrm{e}^{5}$.

A modernização da economia, levada a efeito nos últimos trinta anos, tornou o acesso ao mercado de trabalho mais seletivo, portanto, excludente, assim como aumentou o turnover das pequenas e médias empresas e fortaleceu o poder de barganha dos grandes conglomerados.

Os efeitos desse processo, também já analisados anteriormente, se fizeram sentir nas cidades brasileiras. De um lado, a partir dos anos 60 , intensificaram-se os fluxos migratórios, invertendo a relação campo-cidade e agravando as condições de vida nas médias e grandes cidades, que não estavam preparadas para as novas demandas. De outro, o processo de migração esvaziou as pequenas cidades, com a saída de parcela significativa da sua população, principalmente dos mais jovens, que buscaram outros espaços para viver, destituindo-as de um vetor importante de desenvolvimento local, que é o seu capital humano.

Todo esse processo pode ser resumido em quatro fases que se acumularam ao longo de cinquenta anos: a da urbanização suportável (até meados dos anos 60, quando as cidades ainda ofereciam qualidade de vida e havia ampla oferta de postos de trabalho no setor industrial, na agricultura e no comércio); a da urbanização problemática, nos anos 60-70, quando se intensificou o processo migratório, ocorrendo a inflexão rural-urbano; a da urbanização caótica, no período 70-80, quando se constatou uma queda brutal na qualidade de vida da população que vivia nas médias e grandes cidades; e, por fim, nos anos 90, a da urbanização explosiva, que resultou da inadequação de políticas urbanas anteriores à nova situação, tornando mais difícil a reversão do quadro caótico da fase anterior e, consequentemente, agravando as condições de vida na maioria das médias e grandes cidades brasileiras ${ }^{6}$.

Por urbanização explosiva entende-se não só o crescimento acelerado e concentrado da população em poucas cidades, mas as consequências que esse crescimento provoca nas estruturas urbanas, deteriorando em escala crescente as condições de vida de uma parte significativa da população e aumentando o fosso social. Percebe-se, lembrando Milton Santos, uma "involução" nas condições de vida nas grandes e médias cidades brasileiras, que se agravam com a redução dos postos de trabalho, com o aumento da violência e da criminalidade.

De um lado, considere-se que cada uma dessas fases está relacionada com os vários processos de acumulação de capital ocorridos no Brasil a partir dos anos 60, todos eles, uns mais outros menos, geradores de excludência social. De outro, a ineficácia de políticas públicas para o enfrentamento do intensivo processo de urbanização.

\section{Novos Modelos de Gestão Urbana Participativa}

No que se refere à gestão das cidades, a Constituição de 1988 facilitou o desenvolvimento de novas propostas de políticas urbanas com especificidades locais, o que estimulou a criatividade dos agentes das políticas municipais e a institucionalização da participação popular. É inegável que uma maior interação entre o poder público e a sociedade organizada tem gerado conquistas locais, com amplas possibilidades de serem reproduzidas em outras cidades brasileiras.

Neste sentido, algumas cidades têm adotado experiências alternativas de gestão democrática, com a efetiva participação popular, conseguindo amenizar processos de exclusão social recorrentes em seus municípios e, consequentemente, promovendo a inclusão social dos setores mais fragilizados através da extensão da oferta de serviços urbanos como saúde e educação, bolsa-escola, saneamento básico, renda mínima, infra-

\footnotetext{
${ }^{5}$ Cabe ressaltar que o governo Lula, a partir do Ministério do Planejamento e Coordenação, vem dando sinais que alimenta a esperança de que o Estado estaria sendo organizado para agir nessa perspectiva, o que implica a adoção de políticas regionais também de caráter estruturante.

${ }^{6}$ No Brasil, reconhece-se a década de 1980 como a década perdida do ponto de vista econômico, porém, sob ponto de vista político, a mobilização da sociedade avançou e constitui-se em uma das forças que inflenciou a Constituição Federal a incorporar conquistas sociais históricas represadas.
} 
-estrutura urbana (pavimentação, coleta de lixo, iluminação pública), moradia e até melhoria nos transportes coletivos ${ }^{7}$.

Vale lembrar que as primeiras experiências começaram a surgir a partir dos anos 70, ainda nos governos militares, num contexto por eles chamado de distensão lenta e gradual. Como exemplo, citamos as experiências pioneiras dos municípios de Lages, em Santa Catarina, sob a gestão de um prefeito do Movimento Democrático Brasileiro MDB - tradicional partido de oposição ao regime militar, e as de Nova Esperança, no Espírito Santo, cujo prefeito pertencia ao Partido Democrático Social - PDS - partido que dava suporte político-ideológico ao regime vigente. Ambas tinham em comum a participação da população, não só no levantamento de necessidades mas também na tomada de decisões.

A partir da segunda metade dos anos 80, Soares e Gondim (1998) identificam três ciclos que eles denominam de novo modelo de democracia urbana, marcado pela volta das eleições nas capitais em 1985. No primeiro ciclo estão cidades como Fortaleza, Recife e Curitiba, que passaram a ser governadas por lideranças que se opuseram ao regime militar, possibilitando aos novos governantes intervir na definição de políticas públicas de desenvolvimento local. As características principais desse ciclo, segundo Soares e Gondim, são:

a) a valorização da participação dos movimentos sociais na definição das políticas públicas locais;

b) a hegemonia de uma frente política democrática com um discurso que combinava a condenação ao autoritarismo com propostas de uma democracia substantiva que ultrapassava os marcos da representação parlamentar;

c) mudanças no comportamento da esquerda, que passou a combinar reivindicação com interlocução direta com as agências estatais, ao invés de adotar posturas meramente contestatórias.
O segundo ciclo abre-se com as eleições de 1988, mais precisamente com a vitória do Partido dos Trabalhadores - PT - em grandes centros urbanos como São Paulo, Porto Alegre e Vitória. O marco importante desse ciclo é a desmistificação conservadora de que a esquerda não sabe governar.

Já o terceiro ciclo caracteriza-se pela adoção de mecanismos de participação direta, em que o orçamento participativo e os conceitos de parceria e desenvolvimento econômico local passam a ser determinantes para uma administração bem sucedida.

Com essas experiências, acumuladas a partir do final dos anos 80 e durante os anos 90, as políticas públicas no $\mathrm{Brasil}^{8}$, num crescendo, ganharam relevância, na medida em que muitas cidades brasileiras tomaram iniciativas orientadas para a redistribuição dos recursos públicos em favor dos grupos sociais mais vulneráveis, promovendo a inclusão da população nos processos decisórios. Essas experiências servem de contraponto às políticas urbanas desenvolvidas no Brasil a partir de 1960, adotadas de cima para baixo durante o período autoritário (1964 a 1981), mas também às práticas de gestão adotadas a partir da recomposição democrática, com a eleição para os governos estaduais a partir de 1982.

\section{A Concepção de Política Urbana Presente no Orçamento Participativo}

Os processos de globalização têm agravado a exclusão social até mesmo nos países mais desenvolvidos, porém com consequências mais perversas nos países subdesenvolvidos. É notório, entretanto, que existem muitas resistências a esses processos que se materializam politicamente através de amplos movimentos de contestação e, no campo prático, através de experiências alternativas de gestão pública. Existem muitas

\footnotetext{
Não é objeto deste texto discutir detalhes das diversas experiências de gestão democrática. Aos interessados em discutir essa questão com mais pormenor, sugerimos a leitura de Soares e Gondin, Figueiredo e Lamounier, Lesbaupin, Santos, dentre outros, todos citados no final deste trabalho.

${ }^{8}$ Não só em Porto Alegre, onde o PT governa por quatro mandatos consecutivos, mas também em prefeituras dirigidas por partidos conservadores mais adeptos da democracia representativa, conforme estudo realizado por Figueiredo, 1997.

9 As experiências são inúmeras e vêm marcando as administrações públicas municipais. A mais conhecida, reconhecida e recomendada é a de Porto Alegre, que tem a hegemonia do Partido dos Trabalhadores já no seu quarto mandato consecutivo. Outras, dirigidas por partidos que se inserem no campo conservador, são experiências também inovadoras e merecem ser destacadas. Figueiredo e Lamounier (1997:13) citam “os exemplos de criatividade, seriedade e coragem administrativa de dez cidades brasileiras, quais sejam: Curitiba (PR), Bauru (SP), Belo Horizonte (MG), Campinas (SP), Praia Grande (SP), Campo Mourão (PR), Joinville (SC), Osasco (SP), São Paulo (SP) e Vitória (ES)", as quais, na opinião dos autores, "são cidades que dão certo" graças às iniciativas de "envolvimento da comunidade e busca contínua de soluções alternativas para elevar o bem-estar dos cidadãos". Os autores fazem referência apenas às experiências de Belo Horizonte, administrada pelo Partido dos Trabalhadores e, curiosamente, omitem outras igualmente exitosas, principalmente a de Porto Alegre.
} 
experiências de gestão democrática implantadas por várias prefeituras no Brasil ${ }^{9}$, algumas delas governadas por partidos conservadores que se utilizam de instrumentos progressistas.

Muito se tem escrito e teorizado a partir delas. Assim, vale a pena resgatar as contribuições teóricas sobre os vários projetos alternativos existentes. Não se trata de uma discussão meramente acadêmica, mas elaborações teóricas construídas a partir da realidade social. Segundo Santos (2002: 457), essas experiências "Consideradas em conjunto, (...) são, de fato, uma forma de globalização contra-hegemônica".

Dessas, o Orçamento Participativo (OP) é um dos instrumentos mais importantes. Ao possibilitar a participação da população na definição de investimentos, instaurou, segundo Genro (1997:12), “um novo centro decisório que, juntamente com o Poder Executivo e o Legislativo, democratizaram efetivamente a ação política e integraram os cidadãos comuns num novo 'espaço público'. Mais ainda, "Um espaço público não-tradicional, que potencializou o exercício dos direitos da cidadania e instigou os cidadãos a serem mais exigentes e mais críticos" (idem).

Ainda segundo Genro (idem:12), se referindo a Porto Alegre, onde foi vice e prefeito, "Este novo centro decisório, que incidiu diretamente sobre o caráter e a oportunidade dos investimentos públicos, foi fundamental para gerar distribuição de renda e contribuir para a socialização da política".

A experiência de Porto Alegre, amadurecida pelo tempo e pelas grandes discussões com a sociedade em geral, ainda segundo Genro (idem: 14), não é perfeita nem resolve a crise do Estado brasileiro, mas permite tirar algumas conclusões. Ao abrir espaço efetivo de participação, o poder público transmuda-se por força do processo de coparticipação que exige que as decisões sejam democratizadas. Mais ainda, democratizam-se também as informações. Quem participa quer saber, quer se informar, o que lhe permite obter mais conhecimento da realidade, das funções do Estado, de suas potencialidades e de seus limites. Nesta perspectiva, as várias edições do Orçamento Participativo adotado em várias cidades brasileiras mostram que esse instrumento de política urbana vem ao longo do tempo se renovando, abrindo caminho, sinalizando para a possibilidade até mesmo de superar a crise do Estado, na medida em que a sua democratização contribui para romper com a histórica subordinação do Estado às elites empresariais, sindicais e políticas.

O Orçamento Participativo, enquanto espaço de um novo centro de poder, possibilita, segundo Genro (1997:16), "as condições para a formação de um novo tipo de cidadão: um cidadão ativo, participante, crítico, que se diferencia do cidadão tradicional...", ou seja, se diferencia daquele que antes se aproximava do poder público por interesse pessoal ou de seu grupo de interesses e, portanto, era facilmente cooptado e se deixava envolver por relações de compadrio.

Outro aspecto importante refere-se às novas relações que se estabelecem entre o Estado e a Sociedade. Segundo Souza (1997:45-47), a experiência do OP possibilitou o rompimento com a visão tradicional da política que considera o cidadão um mero eleitor, que transfere, mediante o voto, a responsabilidade da gestão pública aos governos eleitos. Com o $\mathrm{OP}$, “O cidadão deixa de ser um simples coadjuvante da política tradicional para ser protagonista ativo da gestão pública" (Souza, idem).

Nesta condição, instaura-se um novo processo de democracia direta que não exclui, mas valoriza a democracia representativa.

"O processo de co-gestão é fruto da combinação da democracia direta efetuada pela população no Orçamento Participativo e a democracia representativa em que a população da cidade elegeu prefeito para uma gestão de quatro anos" (Souza, 1997:47).

No dizer de Sader (2002:658), o OP sinaliza "para a socialização da política e do poder", materializando "a alternativa colocada por Gramsci, para quem existem dois tipos de políticos: os que lutam para diminuir a separação entre governantes e governados e os que lutam para superá-la" (idem).

As experiências de gestão pública alternativa no Brasil são, portanto, crescentes e repercutem favoravelmente junto à sociedade, sendo adotadas também por administrações cujos partidos estão no campo conservador. Só para se ter uma idéia, conforme Grazia (2001), citada em Santos e Avritzer (2002:67), no Brasil,

"Entre 1997 e 2000, existiram 140 gestões municipais que adotaram o OP, a grande maioria (127) em cidades de até 500 mil habitantes. Na metade dos casos, 71, essas administrações eram ligadas ao PT, enquanto na outra metade não eram". 
A experiência de Porto Alegre, no que se refere à participação popular, permite a Utzig (1996:213) chamar a atenção para a importância de se valorizar e se preservar esse instrumento democrático:

"A crise que a democracia representativa experimenta no quadro atual não exige - para superá-la - somente o aperfeiçoamento do sistema de representação, o que, no entanto, é muito importante e deve ser feito, especialmente no Brasil, com máxima urgência. Ocorre, porém, que o próprio sistema de representação não poderá ser melhorado se não forem criados instrumentos de decisão mais flexíveis, mais próximos da sociedade e que possibilitem um revigoramento dos valores da democracia. A exigência posta no momento atual, portanto, é a combinação de medidas de melhoria da representação política com mecanismos que assegurem a participação popular direta dos negócios públicos".

\section{A Experiência do Orçamento Participativo em Goiânia}

O Orçamento Participativo de Goiânia ${ }^{10}$ foi lançado oficialmente no dia 6 de Março de 2001, numa terça-feira, menos de três meses após a posse do novo Prefeito de Goiânia, eleito em 2000 por uma Coligação de Esquerda sob a hegemonia do Partido dos Trabalhadores, para governar a cidade durante o período 2001 a 2004. A presença do Prefeito, de todo o Secretariado e Diretores dos órgãos municipais, dos Vereadores da cidade e de um grande número de lideranças populares, sindicais e religiosas atestam a importância do evento. Havia por parte de todos os presentes uma grande expectativa pelo projeto que se estava iniciando.

\section{Dinâmica de Funcionamento do OP}

O OP é um processo permanente de organização que exige muita dedicação e compromisso com os objetivos que se pretende atingir. Vale ressaltar que, em Goiânia, normal- mente os que se envolvem com a dinâmica do OP não são funcionários públicos de carreira. Em geral são militantes dos partidos políticos coligados, contratados para exercerem cargos de confiança sem a exigência de concurso público. Neste sentido, pode afirmar-se que o sucesso do OP depende muito do espírito de militância que envolve a todos. A maioria é oriunda dos movimentos sociais, portanto, acostumados à luta social. Para esses militantes o OP transforma-se, na prática, na oportunidade de realizarem a "conquista do poder" pela população.

A organização do $\mathrm{OP}$ resulta de um longo processo que passa por um conjunto de atividades. Várias reuniões de estudos e de planejamento são realizadas com os seguintes objetivos: definir a base geográfica visando regionalizar todas as atividades do OP; definir a metodologia de trabalho a ser adotada; montar equipes de coordenação e de serviços; elaborar o Regimento Interno para ser votado nos fóruns competentes do OP, através do qual se determina como funcionarão as instâncias deliberativas do Orçamento Participativo.

Isto feito, realizam-se seminários de formação, sempre com a assessoria de militantes mais experientes de outros municípios; promovem-se reuniões com o primeiro escalão do governo, assim como com a Mesa Diretora da Câmara Municipal para apresentar o projeto e solicitar a participação dos vereadores durante o processo. Por fim, a Secretaria Municipal de Comunicação é incorporada tendo em vista garantir o máximo de visibilidade e de divulgação, sobretudo da realização das Plenárias e Assembléias de microrregiões, que são muitas, conforme se verificará mais adiante.

Em Goiânia, o OP já está na sua terceira edição. Para que a população pudesse participar, foram criadas diversas instâncias, cada uma delas com suas finalidades específicas, tais como:

a) Plenárias Populares, com o objetivo de explicar a metodologia de participação e reafirmar a importância da participação popular, uma vez que a Prefeitura está colocando em discussão o orçamento do ano seguinte no que se refere aos investimentos a serem realizados.

\footnotetext{
${ }^{10}$ A primeira experiência do Orçamento Participativo em Goiânia foi no período de 1993 a 1996, período esse em que a Prefeitura de Goiânia também foi governada por uma Coligação cujo Prefeito pertencia aos quadros do Partido dos Trabalhadores.
} 
b) Assembléias Microrregionais. O OP, para facilitar as atividades de seus agentes, dividiu a cidade em 52 microrregiões ${ }^{11}$. $\mathrm{O}$ objetivo dessas assembléias é colher as demandas da população, limitadas em no máximo 5 (cinco) demandas por bairro. Nessas assembléias também se elegem os Delegados e respectivos suplentes, que irão representar a microrregião nos Fóruns de Delegados.

c) Plenárias Temáticas (saúde, educação, desenvolvimento urbano e qualidade de vida, desenvolvimento econômico e cidadania). Nestas plenárias são levantadas questões importantes e apresentadas sugestões a serem contempladas nas políticas públicas do município de Goiânia.

d) Fóruns de Delegados. Nestes fóruns, os delegados e delegadas elegem as prioridades de suas respectivas regiões ou plenárias temáticas e definem quais as obras serão realizadas no próximo exercício. É inevitável o confronto entre os delegados, na medida em que os recursos não são suficientes para atender ao conjunto das demandas. Assim, normalmente as reuniões são bastante acirradas.

e) Plenárias Regionais. Nessas plenárias são eleitos os Conselheiros que formam o COP, Conselho do Orçamento Participativo. Este Conselho tem a finalidade de analisar as prioridades definidas no Fórum de Delegados e aprovar o plano de investimentos do município para o próximo exercício, que é oficialmente entregue ao Prefeito. Com esse gesto, os Conselheiros querem dar respaldo ao Prefeito quando este encaminhar o orçamento definitivo para a sanção dos vereadores.

A terceira edição do OP (2003), ainda em curso, mantém o formato das edições anteriores, porém incorporou novidades substantivas. Desta vez a população não foi convocada para apresentar demandas, mas discutir questões de fundo, a partir do seguinte desafio: "da cidade que temos para a cidade que queremos". O que se pretendeu foi envolver a população, a partir de seu bairro, de sua microrregião e das grandes regiões, para pensar a cidade como um espaço de todos, perceber suas contradições e, num grande fórum, denominado de I Congresso da Cidade ${ }^{12}$, refletir sobre a cidade que queremos no futuro.
Neste sentido, em todas as plenárias, em todas as assembléias, em todos os fóruns, em todos os encontros, as discussões foram com o fim de colher subsídios que orientassem os técnicos da Secretaria Municipal de Planejamento na formulação de grandes diretrizes visando orientar a revisão do plano diretor da cidade, implantado em 1992, como uma das exigências do Estatuto da Cidade.

Este processo consolidou-se com a realização do I Congresso da Cidade de Goiânia, do qual participaram aproximadamente 3500 (três mil e quinhentos) delegados eleitos em diversos fóruns legítimos. O I Congresso da Cidade foi aclamado como fórum permanente para acompanhar a formatação final das grandes diretrizes a serem encaminhadas à Câmara Municipal, pelo prefeito da cidade.

Esta é a dinâmica do Orçamento Participativo de Goiânia.

Para concluir, vale dizer que todo o processo do OP não acontece de forma linear, consensual: pelo contrário, é cercado de muito conflito, gera desconfiança, disputas políticas, sobretudo entre os vereadores que se consideram os únicos representantes do povo no âmbito do município.

$\mathrm{Na}$ verdade, o OP é um espaço público de participação que pertence à população e através dele o governo municipal, paradoxalmente, pode colher dividendos políticos, mas também expõe suas fragilidades, suas ambiguidades e corre riscos de ter sua gestão seriamente questionada. Nesse espaço pode-se jogar o jogo democrático mais bem jogado. Este trocadilho serve para mostrar que o OP, ao ampliar seu espaço de participação, possibilitou que a população, em Congresso, pudesse discutir a cidade para além de suas necessidades mais imediatas, de seus interesses pessoais e de grupos específicos.

Durante o $\mathrm{OP}$ os atores puderam jogar com as mesmas regras, com a mesma bola, na perspectiva de buscarem não só o consenso que é necessário para a gestão da cidade, mas também o dissenso que é necessário para a democracia. Enfim, as relações que se estabelecem entre os atores são de confronto, porém, na perspectiva de se buscar consenso em torno de bandeiras minimamente comuns para a cidade. Nesse espaço, que é público,

\footnotetext{
11 A Secretaria Municipal de Planejamento oficialmente divide a cidade em 81 (oitenta e uma) microrregiões e em 12 (doze) grandes regiões. Essa divisão é necessária para facilitar o planejamento das ações públicas, uma vez que o município de Goiânia tem hoje aproximadamente 1200000 (um milhão e duzentos mil habitantes), distribuídos num território de aproximadamente $740 \mathrm{~km}^{2}$.

${ }^{12}$ O I Congresso da Cidade de Goiânia insere-se na primeira etapa de preparação para a I Conferência das Cidades, a ser realizada em Outubro deste ano, que está sendo organizada pelo Ministério da Cidade, criado pelo governo de Luiz Inácio Lula da Silva.
} 
o prefeito foi seriamente questionado por obras que não realizou e que havia prometido. Mas, ao mesmo tempo, foi a ele oportunizada a possibilidade de defesa, de esclarecimentos, de renovação de compromisso.

O OP é uma das mais inovadoras políticas públicas brasileiras e, portanto, tende a se constituir num centro de poder mais democrático.

\section{Bibliografia}

AGUIAR. M. A. A., 1986, Expansão capitalista e a incorporação de novas áreas: o Norte de Goiás. Dissertação de Mestrado. Faculdade de Economia e Administração. Universidade de São Paulo. Mimeo.

ANDRADE, T. A. e LODDER, C. A, 1979, Sistema urbano e cidades médias no Brasil. Rio de Janeiro, IPEA, coleção relatório de pesquisa $n .^{\circ} 43$.

AVRITZER, L., 2002, “Modelos de Deliberação Democrática: uma análise do orçamento participativo no Brasil", in SOUSA SANTOS, Boaventura de (Org.). Democratizar a Democracia: Os Caminhos da Democracia Participativa. Rio de Janeiro, Civilização Brasileira.

BARAT, J., 1976, Política de desenvolvimento urbano: aspectos metropolitanos e locais. Rio de Janeiro: IPEA, série monográfica, n. ${ }^{\circ} 22$.

BOISIER, S. et al.,1973, Desenvolvimento Regional e Urbano. Rio de Janeiro:IPEA, coleção relatórios de pesquisa, n. ${ }^{\circ} 15$.

BORJA, J., 1994, Entrevistas, in GRIMBERG, Elisabeth, O Futuro das Cidades: São Paulo: Polis, Publicações Polis n. ${ }^{\circ}(16)$.

Y Castells, M., 1998,. Local y Global: La gestión de las ciudades en la era de la información. Madrid. Taurus.

CANO, W., 1993, Reflexões sobre o Brasil e a Nova (Des) Ordem Internacional. Campinas: Editora da Unicamp.

CARDOSO, F. H. e FALETTO, E., 1970, Dependência e desenvolvimento na América Latina. Rio de Janeiro, Guanabara.

CASTELL, M. e BORJA, J.,1996,. "As Cidades como Atores Políticos", Revista Novos Estudos CEBRAP n. ${ }^{\circ} 45$.

FIGUEIREDO, R. e LAMOUNIER, B.,1997, As Cidades que deram certo: experiências inovadoras na administração pública brasileira. Brasília, MH Comunicação.

GENRO, T.,1997, "Orçamento Participativo e a Democracia”, in Orçamento Participativo. A experiência de Porto Alegre. São Paulo, Fundação Perseu Abramo.
Através dele, a população organizada e comprometida com uma sociedade mais justa tem a chance de transformar a política brasileira, historicamente marcada por relações de compadrio, e, como consequência, instaurar uma nova prática política, com consenso e dissenso, com confronto e entendimentos, mas que, acima de tudo, possa contribuir para a construção da cidadania.

HOBSBAWM, E. J., 1977, A era do capital, Rio de Janeiro Paz e Terra.

Paz e Terra. 1992, A era dos impérios. Rio de Janeiro,

LEFEBVRE, H.,1991, O Direito à Cidade, São Paulo, Editora Moraes.

LESBAUPIN, I., 2001, O Poder Local X Exclusão Social: A experiência das prefeituras democráticas no Brasil. Rio de Janeiro, Vozes, $2 .^{\text {a }}$ edição.

MINISTÉRIO EXTRAORDINÁRIO PARA O PLANEJAMENTO E COORDENAÇÃ̃ ECONÔMICA. Programa de Ação Econômica do Governo: 1964-1966.

MINISTÉRIO DO PLANEJAMENTO E COORDENAÇÃO ECONÔMICA, 1967, Plano Decenal de Desenvolvimento Econômico e Social.

Diretrizes de Governo - Programa Estratégico de Desenvolvimento. Julho de 1967.

I Plano Nacional de Desenvolvimento (PND) 1972/74.

-1979).

____ III Plano Nacional de Desenvolvimento

(1980-1984)

Nacionais de Desenvolvimento. Brasília, 1974.

MOTTA, A . R.e PORTO, P. C. S. P., 2001, Alegre Análise das Políticas Urbanas Recentes, in Anais do IX Encontro Nacional da ANPUR Vol. 1, Rio de Janeiro. p. 14 a 24.

OSBORNE, D. e GAEBLER, T., 1995, Reinventando o Governo. Como o espírito empreendedor está transformando o setor público. Brasília: MH Comunicação, 5. ${ }^{\mathrm{a}}$ edição.

PIME, 1984. Desigualdades regionais no desenvolvimento brasileiro. Recife, UFPE/IPEA/SUDENE, 4 vls.

PREBISCH, R., 1986, El desarrollo económico de la América Latina y algunos de sus principales problemas. IDES. V. 26, n. ${ }^{\circ} 103$.

PREFEITURA DE GOIÂNIA/ASSESSORIA PARA ASSUNTOS COMUNITÁRIOS, 2001, 2002 e 2003, Relatórios do Orçamento Participativo. Goiânia. Mimeo. 
SADER, E., 2002, "Para outras democracias", in SOUSA SANTOS, Boaventura de (Org.). Democratizar a Democracia: Os Caminhos da Democracia Participativa. Rio de Janeiro: Civilização Brasileira.

SANCHEZ, F., 1999, Políticas Urbanas em Renovação: Uma Leitura Crítica dos Modelos Emergentes. ANPUR - Revista Brasileira de Estudos Urbanos e Regionais n. ${ }^{\circ} 1$.

SANTOS, B. S., 2002, Orçamento Participativo em Porto Alegre: para uma democracia redistributiva, in Democratizar a Democracia: Os Caminhos da Democracia Participativa, Rio de Janeiro, Civilização Brasileira.
SANTOS, B. S. e AVRITZER, L., 2002, "Introdução: para ampliar o cânone democrático", in SANTOS, B. S. (Org.), Democratizar a Democracia: Os Caminhos da Democracia Participativa, Rio de Janeiro, Civilização Brasileira

SOARES, J. A. e GONDIM, L., 1998, Novos modelos de gestão: lições que vêm do poder local, in SOARES, J. ${ }^{\mathrm{a}}$ e BAVA, S. C., Os desafios da gestão municipal democrática. São Paulo, Cortez.

SOUZA, U.,1997, "A experiência de Porto Alegre", in Orçamento Participativo. A experiência de Porto Alegre. São Paulo: Fundação Perseu Abramo. 